\title{
The principal factors
}

\section{responsible for biodiversity}

\section{loss}

\author{
Vijeta Singh ${ }^{1 *}$, Shikha Shukla ${ }^{2}$ and Anamika Singh ${ }^{3}$ \\ ${ }^{1}$ ChemGeneics Research Foundation, Biotechnology Company in Noida, 201301 UP, India \\ ${ }^{2}$ RRPG College, Amethi, UP, India \\ ${ }^{3}$ Vardhman Degree College, Bijnor, UP, India
}

Received: 28 December, 2020

Accepted: 20 January, 2021

Published: 21 January, 2021

*Corresponding author: Vijeta Singh, ChemGeneics Research Foundation, Biotechnology Company in Noida, 201301 UP, India, Tel: +1(610)-931-6612, +919990250103; E-mail: vijetasingh1@gmail.com; singh. vijeta1681@gmail.com

ORCID: https://orcid.org/0000-0001-5756-8041

Keywords: Biodiversity; Habitat; Climate change; Overexploitation

https://www.peertechz.com

\section{Check for updates}

\begin{abstract}
The exclusive attribute of the planet earth is the presence of life, and the remarkable trait of life is the variety or the diversity, which is also known as biodiversity. As per ScienceDaily news 2020, it is assessed that about 15 million distinct species are present on earth and only 2 million of them are presently recognized by science. Biodiversity is diminishing at an alarming pace. It is our responsibility to protect biodiversity as efficaciously as possible. In the previous few years lot of emphasis has been laid on establishing that biodiversity loss is one of the tremendous problems which can threat even the very own existence of human race on earth, if left neglected. It is high time, we put our sincere efforts in understanding the underlying causes responsible for the loss of various species on our planet. The present review discusses the principal factors responsible for the loss of biodiversity such as pollution, habitat loss, hunting, introduction of invasive species, overexploitation of preferred species, climate change and natural disasters.
\end{abstract}

\section{Introduction}

Biodiversity in most simple terms means the diversity of life. The internationally agreed definition as per Convention on Biological Diversity (CBD) is "the variability among living organisms from all sources including, inter alia, terrestrial, marine and other aquatic ecosystems and the ecological complexes of which they are part; this includes diversity within species, between species of ecosystem" [1].

Why is Biodiversity such a big deal? The presence of complexity of life or Biodiversity on the planet earth determines the capability of nature to provide the resources required for human existence. Quoting in other words, the mere sustenance of humanity depends on Biodiversity. Even more, the poor people are affected the most by biodiversity loss as they directly depend on biodiversity to meet their daily needs for subsistence. Biodiversity secures various resources for our survival from uncontaminated water, air, and food to traditional and modern medicines [2] Biodiversity loss is not only an environmental problem, but it would also eventually turn to developmental challenge if left neglected. Development boosts is at higher risk due to loss of biodiversity loss. The uninterrupted biodiversity loss could lead to less nutrition, decreased wild foods, impoverished pollination, and subordinate and less irrepressible agriculture systems [3]. This can further result in more vulnerability to Agrichemicals, decreased traditional medicines access, less chance for development of drugs, further leading to surpassing disease strains [4].

\section{Principal causes for the loss of variety of life on earth}

The numerous factors are responsible for the loss of Biodiversity (Figure 1) such as pollution, habitat loss, hunting, introduction of invasive species, overexploitation of preferred species, climate change, and natural disasters.

\section{Pollution}

Living organisms have developed over an extended period, however they strive to adopt to existence on a polluted planet. Air pollutants such as soot, dust, ammonia, or carbon dioxide can directly and indirectly influence biodiversity.

\section{Air pollution}

Air pollutions influence the respiratory apparatus of the 


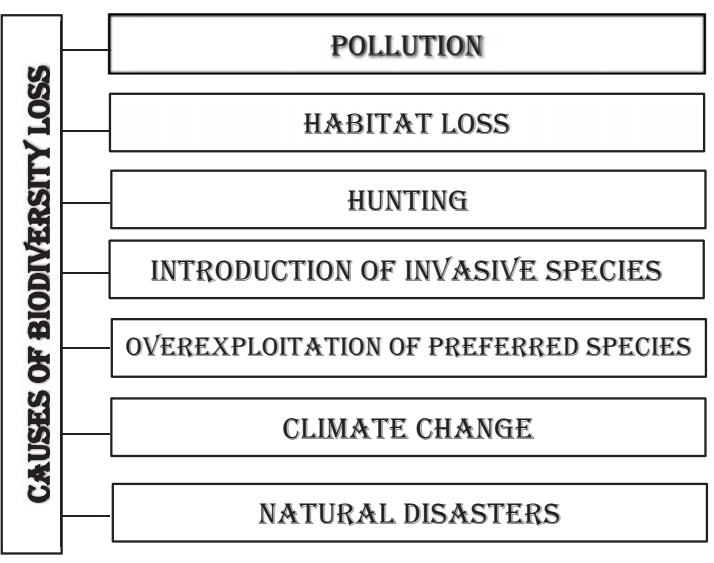

Figure 1: The causes of Biodiversity loss.

animals and negatively impact their well-being including the egg laying capability and behavioral alterations [5]. Air pollution is also known to influence the reproductive ability of the animals and hence success in breeding [6]. The indirect influence of air pollution on animals is difficult to evaluate as it is difficult to examine in controlled environment. The tremendous discharge of greenhouse gases such as nitrous oxide, carbon dioxide, methane is swiftly modifying the climate of the earth. The animals and plants find it difficult to adjust and this influence the biodiversity. Acid rain is other pollutant, and it causes enhanced build-up of the mucus in fish gills leading to suffocation. Soil prone to acid rain has diminished activity of microbes [7]. This influences the food chain and other forms of life too.

\section{Water pollution}

Water pollution had detrimental effect on biodiversity. Chemical fertilizers generally contain nitrogen and phosphorous and are added to soil to boost the crop productivity. Nitrogen and phosphorous sweep away from the soil to the water bodies or underground. The presence of these nutrients in the water bodies lead to eutrophication or excessive plant growth. Eutrophication causes the depletion in the oxygen level which is deleterious for biodiversity. Fish and other aquatic animals die because of lack of dissolved oxygen in water. Alike fertilizers, pesticides may also accumulate in water bodies. The pesticides negatively affect non-flowing waterbodies such as lakes and ponds given the fact that fertilizers are not washed away and animals in water bodies have difficulty in reproducing [8].

Various anthropogenic activities such as production of cement, cars; mining etc. lead to the introduction of heavy metals such as arsenic, cadmium, mercury into the water bodies [9]. Heavy metals affect the behavior as well as the survival rates of aquatic animals specially fish. Further, events such as oil spills greatly impact the wildlife specially in the deeper oceans. The birds and the larger animals display the apparent hostile effects. Oil spills cause disruption of the animal senses, suffocation, impair the vital organs of the organisms, reduction in growth rates and induce the higher mortality of the larvae [10]. Like the oil spills, plastic stays in the environment for longer time-period and hence influence the wildlife. Lager animals particularly turtles fail to regurgitate causing internal injuries leading to death. It has been noticed that the seabirds like Layson albatross upon consumption of plastic die prior to fledging the nest. Microplastics in the environment also impact the survival rate of larvae, diminished food consumption and gradually weight loss in aquatic animals [11].

\section{Soil pollution}

Soil pollution is another factor adversely affecting biodiversity. Soil contaminated with heavy metals greatly impact the welfare of the microorganisms essential for the sustaining life of the living organisms. The excess of heavy metals present in the soil are not easily broken down and are accumulated by plants [12]. The over-use of fertilizers, pesticides and antibiotics used in agriculture is also very deleterious for the biodiversity. These agricultural pollutants such as nitrogen from fertilizers alter the $\mathrm{pH}$ and the nutrient level of the soil. The enhanced presence of nutrients in the soil causes the vigorous growth of grass species, leading to stifle in the growth of wildflowers, essential for bees and other pollinating insects [13]. This greatly impacts the biodiversity.

Light pollution such as the use artificial light too has negative impact on the biodiversity. The late-night streetlights, lights from the buildings, vehicles headlights etc. have specially affected the nocturnal animals such as bats. The feeding activity of bats has decreased and their emergence from roosts have been found to be delayed in artificial lights. The behavior of the moths is also largely affected by the light pollution. Moths are prey for other species and pollinators of many species [14].

Noise pollution has also been reported to have negative impact on biodiversity. The studies have reported that birds in noisier areas begin laying less eggs as it masks the important territorial calls birds make [15]. The machinery noise in Brazil at a mining site was found to impact wildlife. Species numbers declined at sites nearer the mine and were higher farther away [16].

\section{Habitat loss}

The hefty menace to biodiversity and the vital discernment for species extinction is habitat loss. This is a grave issue both for wildlife as well as humans. Habitat and wildlife are causally related. For the active working of the ecosystem to reap the benefits, for which we confide in for our existence, we cannot risk neglecting the wildlife. The destruction, degradation and fragmentation of habitat are the three predominant categories of habitat loss [17].

The habitat destruction is the massive destruction of the natural habitat of the species that it becomes incapable of upholding the native ecosystems and the species. This ultimately results in species extinction i.e., biodiversity loss. The cutting the forests for preparing the fields for agricultural use, filling the wetlands and mowing fields for creating residential or commercial sites, harvest of the fossil fuels, etc. are all examples of habitat destruction [18]. 
Development of agricultural practices, reduced resources such as food, water, air quality, mining, pollution, logging, catastrophic fishing activities, activities related to urbanization, and the interruption of processes related to ecosystem are the predominant elements of degradation of habitat. The habitat degradation affects both the species dwelling in the habitat and the humans both. The erosion, depletion of nutrients and desertification cause the further loss of the degraded land [19].

Habitat fragmentation is another gigantic issue arisen due to human developmental activities. Human beings for the purpose of development and to meet the never ending needs to expand even at the cost of extinction of their own species converts large wild areas into smaller fragments of land. These split up areas break down the habitats of the animal and plant species, isolate animal communities, compressing genetic diversity [20].

\section{Hunting}

Hunting is the root cause of extinction of large numbers of animals holding position in food web. Due to this, the various species in the region are adversely affected as they face food scarcity or complete food unavailability compared with the normal situation. Hunting is extensive operator of loss of biodiversity. Hunting activities exert a considerable burden on wildlife, provoking immense downturn of wildlife and leading to disturbed and inefficient ecosystems. In most extrude situations, overhunting can lead to the elimination of large mammals in contrarily healthful unharmed habitat, compelling transition in forest structure [21].

\section{Overexploitation of preferred species}

Overexploitation is the collection of species from their natural habitat at higher estimates than the native communities can retrieve. Presently, nearly one third of the earth's vertebrates facing extinction are vulnerable due to overexploitation. Extreme fishing and hunting are the examples of overexploitation. Passenger pigeons which were once very commonly seen are the sufferers of overhunting. Similarly, various creatures both plants and animals are collected to be used as pets, trophies, or souvenirs. Such collections are illegal and usually called as poaching [22].

Overexploitation of plants which have medicinal values have eventuated in their loss from native habitats. Many plants such as Drosera sp., Gnetum sp., pitcher plants, Psilotum sp., Napenthes Khasiana etc. are relentlessly hunted and collected for academic tutoring and laboratory experiments. Similarly, various orchids have also been overexploited [23].

\section{Climate change}

The biodiversity and climate change are strongly associated. Even though the climate has consistently altered during the whole of earth's history with ecological communities and species evolving and extinguishing, accelerated climate change disturbs ecological systems and species capability to acclimate and hence the loss in biodiversity enhances. The swift climate change, stimulating biodiversity loss jeopardize human interests and security for clean water, air, medicines, and additional natural resources we depend on, would be difficult to attain due to reduced or vanished flora and fauna they are obtained from. Climate change, beside other components such as habitat loss, land degradation, hunting, overexploitation of certain species etc., is turning up as a high threat to biodiversity on earth [24].

\section{Invasive species}

The introduction of invasive species is the tremendous threat to biodiversity crisis. The species, which is not native to the ecosystem, arrives or is introduced mostly via humans in the new ecosystem and start to pullulate is called as invasive species. Such species are detrimental as they effect the ecosystem disproportionately compared to any other species. Most of the new species introduced in the ecosystem do not become invasive, but few of them turn into invasive species and adversely affect the ecosystem [25]. The invasive species wrack up the native ecosystem in many ways such as they modify the habitat, import pathogens, are herbivorous on plants in native ecosystem, lead to decline of genetic diversity by hybridizing with natives, for the resources they directly compete with and prey on the native species [26]. The prevention of biodiversity loss is a huge developmental issue as the climate change and hence demands further ardent commitment and response from the communities [27].

\section{Natural disasters}

Natural catastrophes, for instance volcanos, wildfires, floods, hurricanes, draughts, epidemics, tsunamis etc. cause a heavy loss of biodiversity [28]. In humid tropical areas such as central Africa, eastern and northern Australia, some areas of South America floods are common. The tropical areas harbor lot of vegetation and vast number of animals survive in the vegetation. Due to flooding, large amount of nutrients from the soil gets washed away. Drought too led to dry soil and decline in the level of water table [29]. In this situation, both animals as well as plants suffer.

Similarly, wildfires in the thickly wooded forests and earthquakes significantly disrupt the life of the organisms and thus affecting biodiversity. Volcanoes frequently wreck animals and plants in the adjoining areas. Epidemics occasionally wipe out vast majority of the population. The occurrence of epidemics in nature is normally restricted to certain population of animal or plant since the pathogen is usually species specific [30].

\section{Conclusion}

The primary cause for biodiversity loss is due to the impact of mankind on world's natural system. The people have profoundly modified the environment. Several factors discussed in the review such as pollution, hunting, invasive species, habitat loss and degradation, exploitation of natural resources etc. are the conducive factors for biodiversity loss. The phenomenon of biodiversity loss has severe negative impact on all the living organisms including human beings. It is our responsibility to save our planet and take some crucial steps to 
prevent the loss of biodiversity. This is highly significant if we wish to secure an inhabitable planet for next generation and for all the plants and animals.

\section{References}

1. Wilson EO (ed.) (1988) Biodiversity. The National Academic Press, Washington DC. Link: https://bit.ly/38ZQ4kV

2. Alves RR, Rosa IM (2007) Biodiversity, traditional medicine, and public health: where do they meet? J Ethnobiology Ethnomedicine 3: 14. Link: https://bit.ly/3bVDsgv

3. Isbell F, Reich PB, Tilman D, Hobbie SE, Polasky S, et al. (2013) Nutrien enrichment, biodiversity loss, and consequent declines in ecosystem productivity. Proceedings of the National Academy of Sciences of the United States of America 110: 11911-11916. https://bit.ly/3o3vGU6

4. Roe D, Seddon N, Elliott J (2019) Biodiversity loss is a development issue: a rapid review of evidence. IIED Issue Paper, IIED London. Link: https://bit.ly/2LRF2oV

5. Sanderfoot OV, Holloway T (2017) Air pollution impacts on avian species via inhalation exposure and associated outcomes. Environmental Research Letters 12: 083002. Link: https://bit.ly/35TKOxm

6. Mohallem SV, de Araújo Lobo DJ, Pesquero CR, Assunção JV, de Andre PA, et al. (2005) Decreased fertility in mice exposed to environmental air pollution in the city of Sao Paulo. Environ Res 98: 196-202. Link: https://bit.ly/3sQpOkW

7. Pennanen T, Fritze H, Vanhala P, Kiikkila O, Neuvonen S, et al. (1998) Structure of a microbial community in soil after prolonged addition of low levels of simulated acid rain. Applied and Environmental Microbiology 64: 2173-2180. https://bit.ly/39TMBUm

8. Bhateria R, Jain D (2016) Water quality assessment of lake water: a review. Sustain Water Resour Manag 2: 161-173. Link: https://bit.ly/39Kan56

9. Singh V, Verma K (2018) Metals from cell to environment: connecting metallomics with other omics. Open Journal of Plant Science 3: 001-014. Link: https://bit.ly/3is9RMO

10. Brussaard CP, Peperzak L, Beggah S, Wick LY, Wuerz B, et al. (2016) Immediate ecotoxicological effects of short-lived oil spills on marine biota. Nature communications 7: 11206. Link: https://bit.ly/39RPWmR

11. Wright SL, Rowe D, Thompson RC, Galloway TS (2013) Microplastic ingestion decreases energy reserves in marine worms. Current Biology 23: R1031-R1033 Link: https://bit.ly/3oZbO5S

12. Singh V, Tripathi BN, Sharma V (2015) Interaction of Mg with heavy metals (Cu, $\mathrm{Cd}$ ) in $\mathrm{T}$. aestivum with special reference to oxidative and proline metabolism. J Plant Res 129: 487-497. Link: https://bit.ly/391ttVc

13. Klein AM, Vaissière BE, Cane JH, Steffan-Dewenter I, Cunningham SA, et al. (2007) Importance of pollinators in changing landscapes for world crops. Proc Biol Sci 274: 303-313. Link: https://bit.ly/3qCDmyw

14. Macgregor CJ, Evans DM, Fox R, Pocock MJ (2017) The dark side of street lighting impacts on moths and evidence for the disruption of nocturnal pollen transport. Glob Chang Biol 23: 697-707. Link: https://bit.ly/2Y2wmhT
15. Wouter H, Holleman LJM, Lessells CM, Slabbekoorn H (2011) Negative impact of traffic noise on avian reproductive success. Journal of applied Ecology 48 210-219. Link: https://bit.ly/35WQrL5

16. Duarte MHL, Sousa-Lima RS, Young RJ, Farina A, Vasconcelos M, et al. (2015) The impact of noise from open-cast mining on Atlantic forest biophony. Biological Conservation 191: 623-631. Link: https://bit.ly/39KHVQx

17. Klappenbach L (2020) Habitat loss, fragmentation, and destruction ThoughtCo. Link: https://bit.ly/3iFsUUh

18. Martins IS, Rosa IMD Pereira HM (2018) Projecting impacts of global landuse scenarios on biodiversity change across scales and species groups. 5th European Congress of Conservation Biology. Link: https://bit.ly/3bWOBQ4

19. Carrete M, Tella JL, Balanco G, Bertellotti M (2009) Effects of habitat degradation on the abundance, richness, and diversity of raptors across Neotropical biomes. Biological Conservation 142: 2002-2011. Link: https://bit.ly/3bTZIr2

20. Bright PW (1993) Habitat fragmentation-problems and predictions for British Mammals. Mammal Review 23: 101-112. Link: https://bit.ly/39LPNRQ

21. Symes WS, Edwards DP, Miettinen J, Rheindt FE, Carrasco LR (2018) Combined impacts of deforestation and wildlife trade on tropical biodiversity are severely underestimated. Nature Communications 9: 4052. Link: https://go.nature.com/35WtyaC

22. Hammerschlag N, Gallagher JA (2017) Extinction risk and conservation of the earth's national animal symbols. Bioscience 67: 744-749. Link: https://bit.ly/391vdxm

23. Bodeker G, van Charlotte K, Emma W (2014) The Journal of Alternative and Complementary Medicine. 810-822. Link: https://bit.ly/2XVCngt

24. Abrahms B, Dipietro D, Graffis A, Hollander A (2017) Managing biodiversity under climate change: challenges, frameworks, and tools for adaptation. Biodiversity Conservation 26: 2277-2293. Link: https://bit.ly/35UjMWk

25. Linders TEW, Schaffner U, Eschen R, Abebe A, Choge SK, et al. (2019) Direct and indirect effects of invasive species: Biodiversity loss is a major mechanism by which an invasive tree affects ecosystem functioning. J Ecol 107: 2660 2672. Link: https://bit.ly/3qARzMb

26. Doherty TS, Glen AS, Nimmo DG, Ritchie EG, Dickman CR (2016) Invasive predators and global biodiversity loss. Proc Natl Acad Sci U S A 113: 11261 11265. Link: https://bit.ly/2XUldj8

27. Kilpatrick AM, Salkeld DJ, Titcomb G, Hahn MB (2017) Conservation of biodiversity as a strategy for improving human health and well-being. Philos Trans R Soc Lond B Biol Sci 372: 20160131. Link: https://bit.ly/3nZJijs

28. Rondeau D, Perry B, Grimard F (2020) The Consequences of COVID-19 and Other Disasters for Wildlife and Biodiversity. Environ Resource Econ 76: 945 961. Link: https://bit.ly/3qCaYwe

29. Chapin FS, Diaz S (2020) Interactions between changing climate and biodiversity: Shaping humanity's future. Proceedings of the National Academy of Sciences 117: 6295-6296. Link: https://bit.ly/39LQwm2

30. Isbell F (2010) Causes and Consequences of Biodiversity Declines. Nature Education Knowledge 3: 54. Link: https://go.nature.com/3bW1IVm

Copyright: (C) 2021 Singh V, et al. This is an open-access article distributed under the terms of the Creative Commons Attribution License, which permits unrestricted use, distribution, and reproduction in any medium, provided the original author and source are credited.

Citation: Singh V, Shukla S, Singh A (2021) The principal factors responsible for biodiversity loss. Open J Plant Sci 6(1): 011-014.

DOI: https://dx.doi.org/10.17352/jps.000026 